
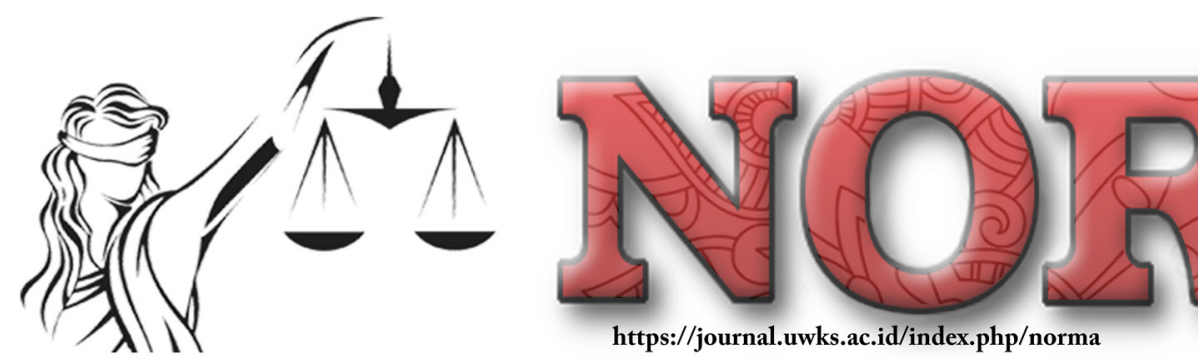

\title{
Legal Action for Pre-Project Selling Based Buyers Whose Apartment Specification Have Changed Without Prior Approval
}

\author{
Anggit Atma Yuwita \\ Legal Observer \\ e-Mail: atma.anggit@gmail.com
}

\begin{abstract}
:
One of the alternatives that can be used as a residence is an apartment. This study aims to know and analyze how the apartment buyers' dispute settlement is experiencing changes in the apartment location without prior notification and approval. This is normative legal research that will explore the legislation's contents. Based on the study results, the sale and purchase of apartments done by ordering then made a Sale and Purchase Agreement (PPJB) that ensures the apartment will not be sold to others and delivered according to the time specified. Besides, it also regulated in Law Number 8 the Year 1999 concerning Consumer Protection and Law Number 20 the Year 2011 on Flats. Therefore, in case of misuse in the sale and purchase of an apartment, the consumer may initiate legal action based on the existing PPJB and Consumer Protection Law.
\end{abstract}

Keywords: PPJB, Apartment, Consumer

\author{
Article's History: \\ Received: \\ 28 January, 2021; \\ Received in revised form: \\ 11 February, 2021; \\ Accepted: \\ 11 February, 2021; \\ Published: \\ 11 February, 2021. \\ DOI:
}

10.30742/nlj.v17i3.1228

\section{INTRODUCTION}

Apartments are an alternative to life and can be obtained by transferring rights, including buying and selling, exchanging, renting, and grants. The sale and purchase of apartments are carried out by ordering or indenting in advance, which is then outlined in the form of a preliminary agreement or sale and purchase agreement, which is better known as the Sale and Purchase Agreement (PPJB) as a guide to safeguarding the interests of the parties. In other words, this agreement is used to obtain down payments from consumers to facilitate apartment construction. This step is a good step for business actors in carrying out housing development because the apartment is not physically available. The existence of a Sale and Purchase Agreement guarantees that the apartment will not be sold to other parties by business actors and will be delivered according to the specified time. Apartment applies the separation principle, namely:

1) The principle of vertical separation is the principle of dividing separately, with the aim that each unit of the apartment unit can be owned or occupied singly, individually from other apartment units; 
2) The principle of horizontal separation is the guide that divides, separates, and distinguishes between apartment units' status, which is the private property rights of each "mede-eigenaars" with the land on which their apartment building stands, which is a property together from the "mede-eigenaars.".

Its application has proven that it has been able to regulate the combination of objects of individual property rights and items of the common property of the "mede-eigenaars" in one functional unit.

Development actors may carry out marketing before the construction of an apartment is carried out. Still, apartments that have been built can only be sold for occupation after obtaining a feasibility permit for habitation from the local government. If marketing is carried out before the construction of an apartment is carried out, the construction actor must at least have certainty of space allocation, the certainty of land rights, certainty of tenure status of apartments, permits, apartment construction, and guarantees of apartment construction from the guarantee institution

Apartments that have not been seen physically in practice can be sold. Usually, these apartment units' marketing before the piles are built, developers offer them through exhibitions or booths in malls. This is commonplace for developers wanting to make sure the unit is sold well before the apartment is built. But of course, the developer who offers the unit that has not yet begun construction must already complete construction documents.

Developers usually already have a sample unit to be built so that potential buyers can see or have an idea of the unit they will buy. Investors will decide to buy or not to buy the unit. Investors are willing to buy a unit that has not been built because investors will get a considerable discount or promo price from the developer. This is one of the main factor's investors want to invest in unfinished units. The value given is enormous, much cheaper than buying it in a finished state. Getting a significant enough profit with a little capital by merely paying a down payment of the apartment unit has become a right. When the unit begins to be built, the unit can go on sale.

However, there is a proble $\mathrm{m}$ in society when the objects in the sale and purchase of apartments that have been submitted turn out to be different, either the specifications or the location, which are not following what consumers expect based on the agreement promoted in the brochure. The contract given by the business actor should have provided certainty and availability of facilities. Therefore, it is necessary to describe the buyer's legal protection for an apartment as outlined in the sale and purchase agreement.

\section{PROBLEM FORMULATION}

Legal Action for Settlement Dispute of Pre-Project Selling Based Buyers Whose Apartment Specification Have Changed Without Prior Approval 


\section{RESEARCH METHOD}

This research is normative legal research with a statutory approach.

\section{DISCUSSION}

In the Big Indonesian Dictionary, the meaning of flats and apartments is only distinguished by its facilities. The facilities seem luxurious for the middle and upper classes in the apartment, but it is different from the apartment that offers simple facilities that impress the lower class. However, the two terms in their legal language are referred to as flat. As for the flats that are usually not many floors, only 2 (two) floors are used for middle-class residents. The flats with many floors intended for residents of society's upper strata with luxurious and modern facilities are often referred to as apartments. ${ }^{1}$ The double-decker dwellings seem to have different terms for upper, middle, and lower-class people. This symptom occurs because the lifestyle gap between the layers of society is relatively high. The second reason is that the government introduces different terms. Apartments for the middle class of society, while the lower class people are presented to the term flats, which are the rules regarding apartments, are also regulated under the applicable law's supervision. ${ }^{2}$

There is no legal basis regulating apartments because it has been summarized using only Law Number 20 of 2011 concerning Flats (referred to as the SARUSUN Law). Article 1 point 1 of the SARUSUN Law affirms that a flat is a multi-store building built in an environment divided into functionally structured parts, both horizontally and vertically, and constituting separate units for places. A dwelling equipped with a common share, everyday object, and common land.

Some of the main things that must be considered so as not to cause losses when there are a sale and purchase of an apartment, things that need be regarded as include, namely:

1) The buyer must identify the developer or company that builds the apartment. Is the developer or the company bona fide or a company that has a black history.

2) Buyers must know the land ownership status. Don't let an apartment be built on someone else's land.

3) In the construction of an apartment, the buyer must pay attention to whether the apartment construction has fulfilled all permits such as a building permit (IMB), location permit, and master certificate. And one of the most important requirements, namely in conducting a sale and purchase agreement is a building permit (IMB).

4) Collateral for apartment or apartment loans must also be ensured. What is worrying is if it turns out that the flats or apartments to be purchased are still collateral

\footnotetext{
${ }^{1}$ Adrian Sutedi. (2010). Hukum Rumah Susun dan Apartemen. Jakarta: Sinar Grafika, p. 156

${ }^{2}$ Ibid.
} 
for the debts of the developer; if so, the goods that have been purchased will be confiscated by the bank if the developer is unable to pay the debt.

5) It is necessary to double-check all documents. It can be ascertained that there has been an apartment's construction at least $20 \%$ (twenty percent) or not. And must look directly at the extent of the building and when the construction is completed.

Apart from the things mentioned above, the essential thing that can be done to mitigate the risk of a legal relationship in buying and selling apartments is to complete the agreement instrument. However, the sale and purchase of an apartment is a form of agreement, therefore making important clauses and protecting the seller and buyer in the apartment sale and purchase agreement is very important to minimize and overcome the risks that can occur in the process of completing the sale agreement. Buy the apartment.

The enactment of the SARUSUN Law is based on the legal objective of providing legal certainty for the community to obtain a decent house to live in. The price of the home can be reached by the community, especially those with low income. This shows the government's efforts to provide a sense of justice for all citizens. Everything related to the legal aspects of the sale and purchase of an Apartment or Apartment is always related to several things that preceded the sale and purchase transaction of the Flats or Apartments, including concerning the permits of the parties involved according to the House Law Arrange.

The perpetrators in the Flats are divided into four agents, namely as follows: ${ }^{3}$

1) Developer (developer), namely a person or company that expects profits from the development of Flats;

2) User (user), a person or company that benefits from utilizing or owning a Flat;

3) Investor, a person or company that expects to benefit from the invested capital to invest in Flats;

4) Speculator, namely a person or company that helps from speculation on capital placement in Flats' investment.

Article 39 paragraph (1) of the SARUSUN Law states that development actors are required to apply for a certificate of eligibility to function to the Regent / Mayor after completing all or part of the construction of an apartment as long as it does not conflict with the building construction permit (IMB) so that the authority provides all and all tickets regarding the matter in question is the authority of the City or Regency Government.

The arrangement for the sale of Flats or Apartments is also regulated in Article 42 paragraph (1) of the SARUSUN Law, which states that Development Players can carry out marketing before the apartment is carried out. The purchase of Apartment units or Apartments that have recently become prevalent in several areas is indeed inseparable

${ }^{3}$ Ibid, p. 9-10. 
from the massive promotion carried out by developers through print and electronic media and exhibition media at malls scattered in several places.

Referring to Article 43 paragraph (1) of the SARUSUN Law, it is emphasized that the buying and selling process of apartment units before the construction of the apartment is completed can be carried out through a Sale and Purchase Agreement (from now on referred to as PPJB) made before a Notary, and Article 43 paragraph (2) The SARUSUN Law states that the PPJB as referred to in paragraph (1) is carried out after fulfilling the particular requirements for land ownership status, IMB ownership, availability of infrastructure, facilities and public utilities, and construction of at least $20 \%$ (twenty percent), according to the things agreed. . Apart from that, the SARUSUN Law also regulates the prohibitions that need to be considered by the owner of the apartment unit, as stated in Articles 97-104 of the SARUSUN Law.

In general, the Sale and Purchase Agreement (PPJB) is an agreement for the seller to bind himself to sell to the buyer, accompanied by a sign or advance based on the deal. In general, the sale and purchase agreement (PPJB) is made underhand for specific reasons, such as the price paid has not been paid off. The Sale and Purchase Agreement (PPJB) contains agreements, such as the cost, when the settlement time, and the Sale and Purchase Deed (AJB) is made. PPJB is made to create a temporary binding before making AJB in front of the Official for Making Land Deeds (PPAT).

The legal relationship between the developer and the consumer in implementing the sale and purchase agreement for the apartment unit is a manifestation of a lawful act between the two, namely the apartment unit's sale and purchase agreement. As long as the apartment agreement made by the developer and the prospective buyer has not ended, the legal relationship between the two has not ended. The legal relationship between the developer and the consumer ends if it follows the agreement, namely, because the consumer has paid the payment or because the consumer has passed away. ${ }^{4}$

Developers as owners and actors of apartment development have several obligations that must be carried out as agreed. These obligations are dominated by obligations related to the implementation of apartment construction. There is a possibility of default by the developer in implementing the sale and purchase agreement (PPJB) between the developer and the buyer. The sale and purchase agreement (PPJB) between the two parties, namely the developer and the buyer, will be related to risk. Some of the dangers that arise include the following: ${ }^{5}$

1) Developers are too optimistic about their projects. Even though they have not controlled the land, they have not even obtained a location permit so that potential buyers will suffer losses;

2) Possible abuse of pre-marketing by paying money orders by malicious developers

${ }^{4}$ Gunawan Widjaja dan Ahmad Yani. (2008). Hukum Tentang Perlindungan Konsumen. Jakarta: Gramedia Pustaka, p. 30

${ }^{5}$ Imam Kuswahyono. (2004). Hukum Rumah Susun. Malang: Bayumedia Publish, p. 58 
3) The standard agreement format for sale and purchase agreements is usually determined unilaterally by the developer. This causes injustice, especially for prospective buyers.

Therefore it is necessary to make a sale and purchase binding agreement that is useful to reduce disputes in the future. The sale and purchase agreement (PPJB) is carried out before the sale and purchase.

Before arriving at the stage of making PPJB buy and sell apartments or flats, there is a marketing stage. Based on Article 42 of the SARUSUN Law on Marketing confirms that:

1) Developers can carry out marketing before the construction of flat is carried out;

2) If the marketing is carried out before the construction of the apartment is carried out as referred to in paragraph 1 , the construction actor must have at least one:

a) The certainty of space allocation;

b) The certainty of land rights;

c) Confirmation of the tenure status of the apartment;

d) Flat construction permit;

e) Guarantee for the construction of a flat from a guarantor institution.

3) In the marketing carried out before the apartment's construction, as referred to in paragraph 2 (two), everything promised by the development actor and/or the marketing agent is binding as a Sale and Purchase Agreement (PPJB) parties.

After marketing, then the Sale and Purchase Agreement (PPJB) is made. In practice, PPJB is carried out by Property Developers; precisely when the physical building has not been completed, developers usually offer their products through brochures containing plans and production facilities to be sold. Several things that must be considered so that the seller and the buyer do not suffer from losses are:

1) PРJB must clearly explain land and building objects. Starting from the size of the land area, the size of the building area, the map of the land, building architecture, certificates, and ownership rights holders, PBB, Tax Object Selling Value, and so on;

2) Land price per meter, building price, total price, payment method, payment period;

3) Terms and conditions agreed upon by the seller and the buyer;

4) Confirmation evidence related to the obligation to pay taxes, notary fees / PPAT, and other costs associated with buying and selling apartments;

5) Explanation of the level and guarantee from the seller regarding the status of the house or land. Make sure there is no dispute. The buyer has the right to ask to be freed from all lawsuits if the seller experiences an error in giving a statement.

In the Sale and Purchase Agreement (PPJB), there are stages of making a Sale and Purchase Agreement (PPJB). The steps of creating a Sale and Purchase Agreement (PPJB) that must be considered include: ${ }^{6}$ 
1) In making a Sale and Purchase agreement based on the Decree of the State Minister for Public Housing Number 9 of 1995, the PPJB, in general, contains the parties who agree, the obligations for the seller, the description of the sale and purchase binding object, the seller's guarantee, the time for handing over the building, the maintenance of the building, use of facilities, transfer of rights, cancellation of agreements, settlement of disputes;

2) Bring documents such as Tax Deposit Form (SSP), building permit (IMB), blueprint, letter of approval to sell from husband or wife, photocopy of Family Card (KK), photocopy of KTP, and original certificate to the Official for Making Land Deeds (PPAT);

3) Checking Original Certificate at the National Land Agency (BPN);

4) If it has not been registered, BPN will issue a Land Registration Certificate.

After the PPJB process, the next is the process of making a sale and purchase deed; in PPAT, several conditions must be prepared in advance: ${ }^{7}$

1) Documents that need to be prepared by the seller are photocopies of husband and wife ID cards, photocopies of family cards, photocopies of marriage certificates, original land certificates, original United Nations deposit receipts, approval letters from the spouse, death certificate if the spouse dies, approval from the heirs which is legal;

2) Documents that the buyer needs to prepare include photocopies of husband and wife ID cards, photocopies of family cards, photocopies of marriage certificates, photocopies of NPWP;

3) Certificate and PBB inspection conducted by PPAT;

4) Approval of spouses and or legal heirs;

5) AJB fees;

6) Signature of AJB;

7) Change the name.

The provisions of AJB in the Decree of the State Minister for Public Housing Number 09/KPTS/M/1995 concerning Guidelines for House Buying and Selling Bonds confirm that both the seller and the buyer must sign AJB before the PPAT, and the process of making AJB in PPAT is as follows: ${ }^{8}$

1) The parties and at least 2 (two) witnesses attended the signing of the deed at the PPAT;

2) Notary / PPAT will read and explain the contents of the AJB;

3) The parties, witnesses, and PPAT sign the AJB;

4) The local PPAT and BPN shall obtain 1 (one) original AJB sheet. Meanwhile, the seller and buyer each receive a photocopy of the AJB.

\footnotetext{
${ }^{7}$ Ibid.

${ }^{8}$ Ibid.
} 
When the making of the AJB has been completed, the PPAT then submits the AJB files to BPN to turn the certificate's name into the name of the buyer as the new owner of the land that the submission of the documents must be carried out no later than 7 (seven) working days from the deed's signing, based on the Regulation of the Head of the National Land Agency of the Republic of Indonesia Number 1 of 2010 concerning Land Service Standards and Regulation of the Head of the National Land Agency of the Republic of Indonesia, the process of changing land rights or the process of transferring the name of the land title certificate will be carried out correctly following the rules stipulated in the Regulation Head of the National Land Agency. ${ }^{9}$

There is also consumer protection in buying and selling apartments, which is confirmed in Law Number 8 of 1999 concerning Consumer Protection (from now on abbreviated as UUPK) Article 16. Consumers are legally not only limited to buyers, as regulated in Article 1 paragraph (2) of the Company Law affirming that consumers are every person using goods and or services available in society, whether for the benefit of themselves, their family, other people, or living creatures and not for sale.

For consumers in Article 4 UUPK, there are 9 (nine) fundamental consumer rights. Developers or business actors have also divided the rights of developers or business actors in Article 6 of the UUPK. The obligations of a developer or business actor are contained in Article 7 of the Company Law. It is also subject to the prohibitions regulated in Article 8 to Article 17 of the UUPK. Broadly speaking and in general, the ban for developers (business actors) can be divided into:1) Prohibition regarding the product itself, which does not meet the requirements and standards suitable for use or use or exploitation by consumers; 2) Prohibition regarding the availability of information that is untrue, inaccurate, and misleading to consumers. ${ }^{10}$

Apart from the UUPK, regarding the rights and obligations of apartment buyers and business actors or developers, it is also regulated through PPJB when it is made. One of the clauses is that the business actor or developer is required to build according to the agreement, ready to provide compensation for losses. Besides, Article 28 of the SARUSUN Law emphasizes that business actors or developers must meet administrative requirements for apartment construction, including the status of land rights and building construction permits (IMB) that must be clear.

Disputes often originate from fundamental mistakes in the process of forming an agreement. The dispute settlement mechanism that occurs can be carried out by the parties in 2 (two) options, settlement through litigation or settlement through nonlitigation. ${ }^{11}$

\footnotetext{
${ }^{9}$ Eman Ramelan. (2015). Perlindungan Hukum Bagi Konsumen Pembeli Satuan Rumah Susun/Strata title/Apartemen. Yogyakarta: Aswaja Pressindo, p. 49

${ }^{10}$ Resti Nurhayati. (2001). Perlindungan Konsumen Berdasarkan Undang-Undang Nomor Tahun 1999. Majalah Ilmiah Kisi Edisi IX. Semarang: FH Unika Soegijapranata, p. 38

${ }^{11}$ Eman Ramelan, Op.,cit., p. 33.
} 
In Article 46, paragraph 1 of the Company Law, it is stated that the parties that can file a lawsuit or violation by the business actor through the court include:

1) A consumer who is injured or the heir concerned;

2) A group of consumers who have the same interest;

3) Non-governmental organizations that meet the requirements, namely in the form of a legal entity or a foundation, which in its articles of association clearly states that the purpose of establishing the organization is for the benefit of consumer protection and has carried out activities following its articles of association;

4) The government and/or related agencies if the goods and services consumed or used result in significant material losses and/or a few victims.

A consumer who has suffered losses can file a compensation claim directly to the court or outside the court through the Non-Governmental Consumer Protection agency. In contrast, a lawsuit filed by a group of consumers from non-governmental consumer organizations or the government or related institutions can only be submitted to the court.

Consumers who have suffered losses from an apartment sale and purchase agreement whose location is not following the previous deal between a developer or business actor and consumer can sue the business actor or developer through an institution that is tasked with resolving the agreement between consumers and business actors, namely through courts located in the general court environment.

With due observance of the SARUSUN and UUPK Laws' applicable rules, consumer dispute resolution through the judiciary refers to the appropriate general court provisions. So thus, the dispute settlement process through the district court is carried out just like filing an ordinary civil dispute suit, by filing a claim for compensation based on an unlawful act, a lawsuit against promises or defaults, or negligence of the business actor or developer that causes injury, death or loss to the consumer. $^{12}$

Besides, in the sale and purchase of an apartment, before an agreement is made in the sale and purchase agreement, consumers must pay attention to the slightest thing that can harm the consumer at the end of the deal. As with consumers, they must ensure the handover schedule stated in the sale and purchase deed (AJB) and the sale and purchase agreement (PPJB). Because from there, sometimes developers create clauses that put consumers in a weak position. So consumers must be more careful in looking at this clause. If there is no conformity, the consumer must have the courage to ask for changes to the clauses made earlier. Sometimes, the developer will say that the clause is the same as the clause for other consumers with the appropriate legal party format according to the predetermined standard.

${ }^{12}$ Susanti Adi Nugroho. (2008). Proses Penyelesaian Sengketa Konsumen Ditinjau dari Hukum Acara Serta Kendala Implementasinya. Jakarta: Kencana, p. 126-127 
Therefore, beforehand, consumers, especially prospective apartment buyers, must know that the agreement clause is an agreement between the two parties, namely the seller and the buyer, free and not influenced by anybody, person, or institution. So there is no standardization from the government or other legal entities for the legalization of sale and purchase clauses or ratification in the form of the signature of the authorized official or authority and stated on the agreement document.

Besides, it has also been confirmed in Article 4 letter h of the UUPK, which ensures that the consumer's right, namely to get compensation, and/or replacement, if the goods and or services received are not following the agreement or not as it should be and also confirmed in Article 8 paragraph 1 letter $\mathrm{f}$ UUPK that business actors are prohibited from producing and or trading goods and or services that are not following the promises stated in labels, tags, information, advertisements or sales promotions of the said goods or services. From the two articles, the buyer can get compensation following the losses that the consumer has suffered. That is why the sale and purchase agreement in the sale and purchase deed, and the sale and purchase agreement must include the date of handover so that the consumer is entitled to compensation as much as the loss he has received. At the stage of implementing the apartment sale and purchase agreement, both parties must carry out what has been agreed upon or carry out what has become their obligation in fulfilling the contract. In the duty to fulfill the agreement, that is called achievement, whereas if both parties or one of the parties do not meet the obligations according to the deal that has been made, it is called default.

\section{CLOSING}

\section{Conclusion}

For the process of buying and selling flats before the construction of the apartments is completed, PPJB can be carried out in front of a notary after meeting the certain requirements of land ownership status, IMB ownership, availability of infrastructure, public facilities and utilities, and construction of at least 20\% (twenty percent) according to the things promised. PPJB contains agreements such as the amount of the price, the time for repayment, and the making of the AJB. PPJB is made to make a temporary binding before the making of the $\mathrm{AJB}$ is carried out in front of the Official for Making the Land Deed (PPAT); after the making of the AJB is completed, the PPAT submits the AJB file to BPN no later than 7 (seven) days after the deed is drawn up and signed. Both parties' rights and obligations stipulated in the UUPK, apart from those stated in the PPJB, must be considered by both parties so that defaults do not occur. Settlement of buying and selling disputes that cause losses to consumers as buyers can be done through litigation and non-litigation. As a precautionary measure, before an agreement occurs in the sale and purchase agreement, the buyer must pay attention to the slightest thing that can harm the consumer at the end of the deal. 


\section{Recommendation}

Consumers' position in the sale and purchase agreement is fragile even though it has been regulated in the SARUSUN and UUPK Laws. Therefore there is a need for efforts and assistance from the government to make new regulations to provide legal protection to consumers. Consumers have not fully understood the legal actions that consumers have carried out to reclaim their rights; therefore, government assistance is needed to increase consumers' awareness.

\section{REFERENCES}

Burgerlijk Wetboek

Undang-Undang Nomor 8 Tahun 1999 tentang Perlindungan Konsumen Adrian Sutedi. (2010). Hukum Rumah Susun dan Apartemen. Jakarta: Sinar Grafika.

Eman Ramelan. (2015). Perlindungan Hukum Bagi Konsumen Pembeli Satuan Rumah Susun/Strata title/Apartemen. Yogyakarta: Aswaja Pressindo.

Gunawan Widjaja dan Ahmad Yani. (2008). Hukum Tentang Perlindungan Konsumen. Jakarta: Gramedia Pustaka.

Imam Kuswahyono. (2004). Hukum Rumah Susun. Malang: Bayumedia Publish.

Resti Nurhayati. (2001). Perlindungan Konsumen Berdasarkan Undang-Undang Nomor Tahun 1999. Majalah Ilmiah Kisi Edisi IX. Semarang: FH Unika Soegijapranata.

Susanti Adi Nugroho. (2008). Proses Penyelesaian Sengketa Konsumen Ditinjau dari Hukum Acara Serta Kendala Implementasinya. Jakarta: Kencana. 